https://doi.org/10.3342/kjorl-hns.2019.00451

\title{
Optimization of Allergen Panels for Diagnosis of Allergic Rhinitis
}

\author{
Jieun Lee ${ }^{1}$, Jin Kook Kim², Kyung Soo Kim³ ${ }^{3}$ and Chae-Seo Rhee ${ }^{4}$ (iD \\ ${ }^{1}$ Department of Otolaryngology, College of Medicine, Chosun University, Gwangju; and \\ ${ }^{2}$ Department of Otolaryngology, College of Medicine, Konkuk University, Seoul; and \\ ${ }^{3}$ Department of Otolaryngology, College of Medicine, Chung-Ang University, Seoul; and \\ ${ }^{4}$ Department of Otolaryngology, College of Medicine, Seoul National University, Seoul, Korea
}

\section{알레르기 진단을 위한 원인 항원 패널 선정 최적화 연구}

\author{
이지은 ${ }^{1} \cdot$ 김진국 $^{2} \cdot$ 김경수 $^{3} \cdot$ 이재서 ${ }^{4}$ \\ 조선대학교 의과대학 이비인후과학교실, ${ }^{1}$ 건국대학교 의과대학 이비인후과학교실, ${ }^{2}$ \\ 중앙대학교 의과대학 이비인후과학교실, ${ }^{3}$ 서울대학교 의과대학 이비인후과학교실 ${ }^{4}$
}

\author{
Received July 1, 2019 \\ Accepted July 30, 2019 \\ Address for correspondence \\ Chae-Seo Rhee, MD, PhD \\ Department of Otorhinolaryngology, \\ Seoul National University Hospital, \\ 101 Daehak-ro, Jongno-gu, \\ Seoul 03080, Korea \\ Tel $+82-2-2072-3991$ \\ Fax $+82-2-745-2387$ \\ E-mail csrhee@snu.ac.kr
}

The selection of allergen panel is very important to test for innumerable allergens throughout the Korea. However, the allergens studied are heterogeneous depending on the area the patient live and there is no methodological unification. Although, testing panel of allergens should be tailored according to the geographical areas, considering the relatively small Korean Peninsula, common inhalant allergens for test could be retrieved from the published data. Hence, this study is aimed to review the longitudinal variance of allergens in patients with allergic rhinitis live in several regional provinces of Korea, figure out the similarity and differences of sensitized allergens results derived from each study and finally make a guideline for physician in selecting the offending allergens to test. From the inception, studies which analyzing the offending allergens by either ImmunoCAP ${ }^{\circledR}$, Multiple Allergen Simultaneous Test or Skin testing were reviewed and we found that the common sensitized allergens are house dust mites, pollen and mold plus 1-2 notable different allergens according to the specific regions. Especially, a total of $10 \pm 3$ allergens adequately detected most of the sensitization of the major regions of Korea according to each age groups and special regional features. This study suggest that physicians should perform the screening of allergic rhinitis with minimally selected allergen in the light of age categories and special regional features. Standardization of allergens selection process would be predicted to have enormous benefits in establishing an insurance policy, giving sound scientific evidence and monitoring the antigenic variations of the Korean Peninsula. Korean J Otorhinolaryngol-Head Neck Surg 2019;62(11):609-16

Key Words Allergens · Allergic rhinitis · Immunoglobulins · Skin tests.

\section{서 론}

국내 알레르기 비염의 유병률은 학령기 나이에서 $38 \%$, 성 인에서 $20.9 \%$ 정도로 보고된다. ${ }^{1-3)}$ 1999년에 발표된 알레르기

This is an Open Access article distributed under the terms of the Creative Commons Attribution Non-Commercial License (https://creativecommons.org/licenses/by-nc/4.0) which permits unrestricted non-commercial use, distribution, and reproduction in any medium, provided the original work is properly cited.
비염의 유병률이 소아 $15.5 \%$, 성인 $19.3 \%$ 였음을 감안하면, ${ }^{4}$ 알레르기 비염의 유병률이 증가하는 추세라는 것은 부인할 수 없는 사실이다. 알레르기 비염의 정확한 진단과 치료는 알 레르기 비염 환자들의 경제적 의료 비용 부담 개선과 삶의 질의 향상을 위해 중요하다. 또한 원인 물질이 알레르기 항원 인지 혹은 화학물질 및 각종 자극인지 종류를 규명하는 것 은 진단과 적정 치료방법의 선택뿐만 아니라 예방 및 악화 
방지에도 기본이 되므로 원인 항원을 찾는 것이 무엇보다 중 요하다.

주요 감작 항원의 다양성은 내적으로는 개체의 감수성, 유 전적 요인과 관련이 있고 외적으로는 꽃가루 항원의 절대적인 비산 분포량 증가 혹은 항원성 증가와 같은 요인과 관련이 있 다. 일반적으로 50 세 이상에서는 피부 반응도가 감소되어 정 확한 항원 감작 상태를 판단하기 어려울 수 있고, ${ }^{5)} 40$ 대 이후 에는 새로운 항원에 대한 감작이 줄어드는 것으로 알려져 있 다.) 외적 요인으로는 지구 온난화, 산업화, 꽃가루의 비산기 간, 대기오염 등의 영향이 있다. 내외적 요인의 특징을 알면 항원의 종적 변이성이 대한 예측이 가능하며, 이를 근거로 주 요 원인 항목을 그룹화할 수 있다.

피부 단자 검사(Skin Prick Test, SPT)는 IgE 항체-매개 알레르기 질환의 진단의 표준적인 검사 방법으로 임상에서 원인 알레르기 항원을 확인하기 위해 흔히 시행되는 검사이 다. 혈청을 이용한 항원 특이 $\mathrm{IgE}$ 항체를 확인하는 검사로는 Multiple Allergen Simultaneous Test(MAST), Immuno$\mathrm{CAP}^{\circledR}$ 등이 있으며 $\mathrm{SPT}$ 와 더불어 실제 임상에서 많이 사용 된다. 알레르기 항원 패널 제작에 관한 연구는 1990년대 초 국내에 한국형 패널로 소개되어 많은 기관에서 사용되어 온 MAST-chemiluminescent assay(CLA)의 검사 항목이 우리 의 실정과 다소 맞지 않는 부분이 있어 좀더 적절한 항원을 찾고자 하는 필요에 의해서 시작된 것으로 확인이 되며," 현 재 사용되는 항원 패널은 2001년경 서울, 수원, 제주 지역 3차 병원 환자들의 데이터를 기반으로 하여 선정된 50여종 이상 으로 구성된 항원 항목으로, 이후 여러 지역의 주요 항원 연 구 및 환자 진단 시에 주로 참조 및 사용되고 있다. ${ }^{8)}$ 동시에 최대 빈도의 양성률을 갖는 원인 항원을 조사하는 연구가 꾸 준히 진행되어 왔는 바, 이 결과를 바탕으로 검사하는 항원 항목을 단순화하는 방안을 생각할 수 있다. 알레르기 항원 진단 검사에서 항원의 최적 조합이 가져올 이익으로는 검사 비용의 경제성, 검사 시간 단축에 따른 검사자 및 피검사자의 편리성, 진단의 효율성뿐만 아니라 연구 목적으로 여러 기관 에서 시행된 검사 간의 비교 연구나 오랜 기간의 특정 지역의 원인 항원의 역학적·연대기적 변화에 대한 상황 파악이 용 이하여 검사법 관련 가이드라인 작성에도 도움이 될 수 있는 점 등이다. 본 연구에서는 문헌에 보고된 국내의 알레르기 원 인 항원의 변화 양상을 확인하고 알레르기 검사의 역할을 염 두한 항원의 최적 조합(패널) 사용 가능성에 대해 논의 해보 고자 한다.

\section{본 론}

\section{알레르기 검사의 역할}

알레르기 진단을 위한 검사 항원 항목의 그룹화 작업의 가 능성 및 필요성에 대한 논의를 위해서 먼저 알레르기 검사의 역할을 잠시 살펴볼 필요가 있다. 알레르기 검사로 원인 항원 을 확인하는 이유는 정확한 원인 항원 진단에 따라 치료 계 획을 수립하고 예방책을 고안할 수 있기 때문이다. 과거와 비 교하여 알레르기 질환의 유병률이 증가하여, 진단과 치료의 대상자가 늘어나고, 항히스타민 제제 및 스테로이드 제제와 같은 대증적 약물치료의 한계성에 대한 회의가 꾸준히 발생 함에 따라 우리나라에서도 면역치료와 같은 근본적 치료가 도입되어 치료에 적극 이용되고 있는 것도 알레르기 검사 선 택의 중요성에 무게를 더하고 있다. 알레르기 비염 치료에서 면역치료가 근본적인 치료로 인식되는 과도기적 상황에서 과 연 적절한 알레르기 검사는 무엇인지가 바로 중요한 논점인 것이다. 피부 단자 검사가 알레르기 질환 진단에서 표준적인 검사인 것은 명확하나, Allergic Rhinitis and its Impact on Asthma 가이드라인에서 알레르기 면역치료를 상당히 초기 부터 시행 가능한 치료로 인정한 점, 알레르기 비염뿐만 아니 라 알레르기성 천식 질환에서도 면역치료의 대상자가 점차 증 가 추세인 점, 면역치료가 시행되기 위해서는 특정 항원의 존 재가 증명되어야 하는 점, 검사 비용 및 효율을 고려한 편리하 고 정확한 검사를 선호하는 환자들의 성향 등이 기존의 알레 르기 진단 방식에 대해 새로운 구비 조건을 요구하며 개념 전 환을 시도하게 하는 계기를 마련해 주고 있다고 하겠다. 특히 항원 특이 면역치료 시행 시 치료 반응군(response group)을 정의하고 치료 지속 여부를 결정하기 위한 표준화된 치료 반 응 예측 생체 바이오마커(biomarker) 개발 필요성이 대두되 어 많은 경우에서 안정적이며 표준화가 가능하고, 다기관 임 상시험에 사용할 수 있는 대체 표지자를 찾고자 노력하고 있 는 상황이다. 정량적이고 검증된 측정 방법을 강조한 2017년 European Academy of Allergy and Clinical Immunology (EAACI) position paper가 발표된 이후, 가능성이 있는 생체 표지자 분류는 크게 7가지로 나뉘었는데, 그중 항체 분류에 $\operatorname{IgE}$ (항원 특이 $\operatorname{IgE}$, 총 $\mathrm{IgE}$, 항원 특이 $\operatorname{IgE} /$ 총 $\mathrm{IgE}$ ), $\operatorname{IgA}$, 항 원 특이 $\operatorname{IgG} 4$ 가 포함되어 있다. ${ }^{9}$

\section{알레르기 질환의 생체 표지자로서 $\operatorname{IgE}$}

생체 표지자로서 피부 반응 검사는 사용하기에 간편하고 비용 대비 효용성이 높으며, 면역 치료 시행 후 피부 반응이 감소한다는 것이 환자 대조군 연구를 통해 밝혀진 바 있다. ${ }^{10}$ 그러나 검사 방법의 표준화에 대한 문제가 있고, 항원의 농도 
에 따라 결과가 다를 가능성이 있는 단점을 지닌다. 또한 면 역치료를 시작하기 전 원인 항원에 대해 단순 감작된 상태가 아닌 현증 알레르기 상태를 평가하는 것이 반드시 선행되어 야 하는데, 피부 반응 검사는 이 둘의 상태를 분별하기 어렵기 때문에 일부 연구자들은 성분 분해 진단(component-resolved diagnosis)을 시행할 것을 주장하기도 한다. ${ }^{11)}$

혈청 항원 특이 $\mathrm{IgE}$ 의 수치로 면역치료 효과를 평가하고자 한 연구에서, 피하 및 설하 면역치료 모두에서 초기에 이 수치 가 증가하다가 수년 동안 치료 전 수준으로 점진적 감소하는 경향을 확인하였고, ${ }^{12}$ 또 다른 연구에서는 항원 특이 $\mathrm{IgE} /$ 총 $\operatorname{IgE}$ 비율이 특이 $\mathrm{IgE}$ 단독 수치보다 치료 반응을 예측하는 데 중요하다고 역설하였다. ${ }^{13)}$ 무엇보다도, 여러 항원에 다감작 된 상태에서 혈청 특이 $\mathrm{IgE}$ 의 임상적 중요성과 관련하여 수 행된 여러 연구들이 항원 특이 $\mathrm{IgE}, \mathrm{IgG}, \mathrm{IgG} 4, \mathrm{IgA}$ 의 수준 이 시험 항원마다 다르고, $\operatorname{IgE}$ 수준과 알레르기 질환의 중증 도가 연관이 있다고 발표하였다. 특히 피부 단자 검사로 원인 항원을 특정하기 어려운 경우 다감작 소아에서는 혈청 특이 $\mathrm{IgE}$ 의 의미 있는 차이가 나타나므로 다감작된 소아에서 $\mathrm{IgE}$ 의 측정이 효과적인 방법이라고 하였다. 다감작된 성인 환자 역시 마찬가지로 항원들의 피부 단자 검사 결과가 4+로 같게 나오더라도 $\mathrm{IgE}$ 의 수치는 유의하게 다르게 측정되어 다감작 환자 관리를 위해서 $\mathrm{IgE}$ 를 측정하는 것이 더욱 적절하다고 보고하였다. ${ }^{14)} 122$ 명의 알레르기 환자에서 피부 단자 검사와 특이 $\mathrm{IgE}$ 를 측정하여 비교한 결과 특이 $\mathrm{IgE}$ 의 양성 예측률 은 $72 \%$, 음성 예측률은 $80 \%$ 로 단순 감작 상태의 환자와 현 증 알레르기 환자를 구분하고 면역치료를 위한 원인 항원 추 출물을 선택하기 위한 적절한 검사 방법이라고 하였다. ${ }^{15)}$

\section{주요 감작 항원 확인하기}

현재의 국내 의료 환경과 알레르기 치료의 패러다임 변화 를 잘 반영하는 효율적 검사 대상 항원을 설정하는 일은 무엇 보다 중요하다. 과거에서 현재까지 현증 알레르기 상태를 피 부 단자 검사로 정확한 감별이 어렵다는 것을 고려할 때 알레 르기 비염을 진단하기 위해 현재와 같이 50여종 이상의 여러 가지 항원을 모두 검사하는 것이 반드시 필요한가에 대한 의 문은 예전부터 존재하였을 것이란 생각이 가능하다. 국내에 서는 Kang 등 ${ }^{16)}$ 의 1984년 연구에서 112종의 흡입성 항원을 사용하여 피부 단자 검사를 시행하였을 때, 24종의 주요 항원 으로 감작된 항원의 약 $97 \%$ 를 검출하였다고 보고하며 단순 히 많은 수의 항원을 사용하는 것보다는 주요 항원의 선별적 선택이 보다 능률적인 선별 검사에 중요하다고 하였고, 1998 년 $\mathrm{Ko}$ 등 $^{17)}$ 의 연구에서도 21 가지 주요 항원으로 약 $95.6 \%$ 의 항원 감작을 확인할 수 있었다고 하였다. 저자의 2014년 연구
결과에서는 10 여종 미만의 주요 항원만으로 양성으로 밝혀진 환자의 $97 \%$ 까지 검출이 가능했는데, ${ }^{18)}$ 이전 연구 결과와 항 원 개수의 현저한 차이가 있는 까닭은 과거에 비해 근래에 주 요 항원들에의 감작률이 높아진 것이 부분적인 원인일 것으 로 추측된다.

2013년 유럽 알레르기 및 면역 학회(EAACI)는 소아 알레 르기 검사 시행과 관련되어 최신판 제안서에서 알레르기 검 사를 시행함에 있어 항원 패널의 개수와 항목은 환아의 나 이, 알레르기 증상, 지역별 항원의 유병률에 따라 결정해야 한 다고 권고하며 유럽 전역에서 항원 유병률을 조사한 2009년 $\mathrm{GA}^{2} \mathrm{LEN}$ 피부 단자 검사 결과를 선택 결정 근거로 제시하고 있다(Table 1). ${ }^{19,20)}$ 유럽의 경우, 피부 단자 검사 방법의 표준화 를 위해 유럽 14 개 국가, 17 개의 센터에서 시행한 피부단자 검 사를 시행하여 감작률 결과를 근거로 선택된 항원들을 GA${ }^{2} \mathrm{LEN}$ 프로토콜로 만들어 유럽 표준 항원 패널로 사용 권고 하고 있다(Table 2). ${ }^{21)}$ 또한 알레르기 증상이 계절적 패턴일 경 우에는 지역별 항원 차이를 고려한 pollen 항원에 주로 초점 을 두고, 이 경우 증상 기록 일기가 계절성 항원에 대한 양성 검사 결과와 임상 관련성을 확인하여 원인 항원을 결정하는 데 도움이 된다고 하였다. 천식의 진단 치료 지침인 Global Initiative for Asthma 가이드라인에서는 흡입성 코르티코스 테로이드 치료에도 불구하고 천식 증상이 지속 시 알레르기 검사를 시행하고 면역치료를 고려하도록 하고 있으며, ${ }^{22)}$ 이에 근거하여 미국흥부외과의사협회(American College of Chest Physicians)에서는 개인 의원에서 천식환자 검진 시 알레르기 검사 시행의 정당성을 부여하며 미국 전체 지역을 19 개로 나 누고 지역별로 13 개에서 25개의 흔한 항원 조합(cat dander, dog dander, cockroach, house dust mite, mold 항원+지역 별 특이 항원을 추가하는 조합)을 소개하며 지역별 1차 진료 의의 알레르기 검사 항원 선택에 도움을 주고 있다. ${ }^{23)}$

\section{우리나라 주요 감작 항원 관련 연구}

알레르기 항원의 감작은 유전적 소인과 환경적 요인이 관 여하므로, 대상자의 거주 지역에 영향을 받으며 실내 생활, 실 외 생활 모두 영향 요인이 될 수 있다. 우리나라에서는 지금까 지 서울, 부산, 울산, 강원, 제주, 경기 남부 지역에서 알레르기 원인 항원 관련 감작률 및 추이 변화 연구가 시행되어 왔으며 이들 주요 내용은 다음과 같다.

\section{국소 지역별 알레르기 항원 검사 결과}

1996년에 서울 지역에서는 1775명의 환자를 대상으로 피부 단자 검사를 시행하여 Dermatophagoides farinae(Df, 77.6\%), Dermatophagoides pteronyssinus(Dp, 73.3\%), cat(39.9\%), 
Table 1. Clinically relevant sensitization rate (\%) to common inhalant allergens in various European countries

\begin{tabular}{|c|c|c|c|c|c|c|c|c|c|c|c|c|c|c|}
\hline & $\mathrm{AU}$ & $\mathrm{BE}$ & DK & GE & GR & $\mathrm{FI}$ & FR & $\mathrm{HU}$ & IT & $\mathrm{NL}$ & $\mathrm{PL}$ & PT & SW & UK \\
\hline \multicolumn{15}{|l|}{ Indoor } \\
\hline$D p$ & 12.6 & 29.9 & 40.9 & 17.0 & 26.2 & 15.2 & 29.2 & 26.1 & 34.7 & 29.0 & 16.8 & 65.3 & 22.1 & 31.7 \\
\hline Df & 11.4 & 26.4 & 40.7 & 16.1 & 22.9 & 13.9 & 28.8 & 20.6 & 31.9 & 30.6 & 15.3 & 63.5 & 22.1 & 31.0 \\
\hline Blatella & 2.2 & 1.4 & 10.7 & 6.8 & 7.0 & 3.6 & 8.0 & 0.6 & 3.0 & 8.8 & 6.8 & 21.0 & 0.9 & 0.0 \\
\hline Cat & 11.5 & 18.1 & 32.0 & 23.6 & 15.4 & 26.2 & 14.8 & 22.6 & 17.6 & 18.5 & 16.3 & 15.0 & 24.8 & 27.8 \\
\hline Dog & 8.8 & 15.0 & 29.4 & 18.0 & 10.8 & 24.6 & 14.2 & 20.8 & 13.4 & 28.3 & 12.3 & 7.7 & 13.1 & 15.9 \\
\hline Aspergillus & 0.5 & 1.7 & 4.3 & 3.7 & 5.6 & 1.5 & 0.5 & 1.5 & 0.0 & 4.6 & 2.8 & 3.5 & 2.1 & 7.1 \\
\hline \multicolumn{15}{|l|}{ Outdoor } \\
\hline Hazel & 13.3 & 13.5 & 37.8 & 32.4 & 6.5 & 22.9 & 7.4 & 15.9 & 7.2 & 24.4 & 13.3 & 3.9 & 24.8 & 10.3 \\
\hline Alder & 12.4 & 14.3 & 36.2 & 31.7 & 6.5 & 24.6 & 4.8 & 12.3 & 2.3 & 24.2 & 13.6 & 4.4 & 22.8 & 11.1 \\
\hline Birch & 9.5 & 13.9 & 49.1 & 34.1 & 5.1 & 30.0 & 4.0 & 16.2 & 7.7 & 26.5 & 19.6 & 4.4 & 43.4 & 11.9 \\
\hline Olive/Ash & 5.9 & 3.4 & 9.1 & 4.9 & 29.9 & 1.0 & 8.9 & 12.1 & 23.0 & 11.9 & 2.0 & 17.9 & 32.4 & 12.7 \\
\hline Grasses & 20.2 & 24.5 & 64.0 & 34.1 & 42.3 & 18.5 & 19.3 & 37.3 & 18.6 & 34.4 & 30.8 & 31.6 & 71.0 & 50.8 \\
\hline Ragweed & 5.3 & 3.0 & 14.3 & 9.3 & 5.1 & 1.4 & 4.5 & 49.7 & 3.1 & 16.7 & 5.4 & 10.8 & 9.7 & 7.1 \\
\hline Mugwort & 6.9 & 4.7 & 23.8 & 19.1 & 11.7 & 13.0 & 3.5 & 38.8 & 5.8 & 5.8 & 14.9 & 14.6 & 6.2 & 3.2 \\
\hline Parietaria & 1.0 & 0.7 & 4.9 & 3.9 & 20.6 & 0.9 & 3.6 & 2.0 & 30.7 & 8.7 & 2.2 & 14.7 & 0.7 & 16.7 \\
\hline Alternaria & 2.6 & 4.9 & 8.2 & 7.9 & 18.7 & 1.5 & 4.2 & 10.4 & 3.0 & 5.5 & 3.5 & 7.3 & 4.1 & 0.0 \\
\hline Cladosporium & 0.0 & 0.4 & 7.0 & 4.4 & 5.1 & 0.5 & 0.0 & 8.5 & 0.0 & 3.9 & 0.4 & 7.4 & 0.7 & 5.6 \\
\hline
\end{tabular}

Adapted from Burbach GJ, et al. Allergy 2009;64(10):1507-15. ${ }^{20)}$ AU: Austria, BE: Belgium, DK: Denmark, GE: Germany, GR: Greece, FI: Finland, FR: France, HU: Hungary, IT: Italy, NL: Netherlands, PL: Poland, PT: Portugal, SW: Switzerland, UK: United Kingdom, Dp: Dermatophagoides pteronyssinus, Df: Dermatophagoides farinae

Table 2. Standard prick test panel for inhalant allergens

\begin{tabular}{c}
\hline Allergen \\
Hazel \\
Alder \\
Birch \\
Plane \\
Cypress \\
Grass mix \\
Olive \\
Mugwort \\
Ragweed \\
Alternaria \\
Cladosporium \\
Aspergillus \\
Parietaria \\
Cat \\
Dog \\
Dermatophagoides pteronyssinus \\
Dermatophagoides farinae \\
Blatella
\end{tabular}

Adapted from Heinzerling L, et al. Clin Transl Allergy 2013; $3(1): 3^{21)}$

$\operatorname{dog}(32.6 \%)$, mugwort(23.4\%), tree(18.8\%), ragweed(18.2\%), grass(14.1\%), alternaria(6.7\%)의 순서로 항원 감작율이 높게 나타남을 확인하였다. ${ }^{24)}$ 이후, 2002년 1월 2003년 8월까지 서 울에 위치한 한 대학병원에서 502 명의 알레르기 비염 환자에
서 시행한 혈청 내 특이 항체 검사(MAST-CLA) 혹은 피부 단자 검사에서 통년성 항원 323명(64.9\%), 계절성 항원 63명 (12.5\%), 중복 감작 113 명(22.5\%)의 양성률을 확인하였고, 통 년성 항원은 $D f(79,4 \%), D p(68.1 \%)$, house dust(43.8\%), cockroach mix(16.8\%), dog hair(11.0\%)순으로, 계절성 항원은 mugwort(12.3\%), birch alder mix(11.7\%), ragweed(11.1\%), bermuda grass(10.2\%), hazelnut $\operatorname{mix}(9.4 \%)$ 순으로 양성률을 보고하였다. ${ }^{25)}$ 가장 근래의 서울 지역의 데이터는 2014년 대 학병원에 내원한 환자 대상자 7182 명에서 시행한 피부 단자 검사 결과로 2007 2011년 동안 5년 사이 항원 감작률은 약간 의 $64.5 \%$ 에서 $69.7 \%$ 로 전체적으로 증가하는 양상으로 나타 났고, 2007년과 2011년 양성을 나타낸 항원의 빈도 변화는 두 개(beech, hop Japanese)의 항원을 제외하고, 전체 순위가 동일했다 $[D f(75.0 \%)>D p(74.7 \%)>\operatorname{beech}(30.6 \%)>\operatorname{dog}$ $(25.85 \%)>\operatorname{cat}(24.3 \%)>\operatorname{cockroach}(22.6 \%)>$ mugwort $(21.1 \%)>$ hop Japanese $(20.2 \%)>$ crysan $(18.9 \%)>$ oak $(18.9 \%)>\operatorname{hazel}(13.7 \%)>\operatorname{ragweed}(13.6 \%)>\operatorname{alder}(13.0 \%)]$. 이 연구에서는, 13 개의 항원 조합만으로 전체 대상자의 알레르 기 감작 여부를 $97.4 \%$ 까지 확인 가능했고, 나이군별로는 최 소 5 개에서 최대 9 개의 항원 조합을 이용하여 감작된 환자의 92.5 97.3\%의 대상자를 확인할 수 있었다. ${ }^{19)}$

한편, 1981년 1월 1996년 6월까지 15년 기간 동안 부산 지 역 3159 명 환자에서 알레르기 피부 시험 검사상 양성 반응 
을 나타낸 환자의 원인 항원 각각의 분포를 살펴 보면, $D f$ 가 $52.5 \%, D p$ 가 $44.5 \%$ 순으로 높았고, cat, cockroach, straw dust, dog hair, alder, birch, hazel, beech, chrysanthemum, mugwort, ragweed순으로 양성 반응이 높은 것으로 확인되 었다. ${ }^{18)}$ 한편, 원인 항원의 변화 추세를 확인하기 위해서 1981 년 1 12월 사이, 1991년 1월 1996년 6월 사이의 두 기간의 양 성 반응을 나타낸 항원을 비교한 결과, $D f$ 를 제외한 모든 항 원의 양성률이 증가하는 양상을 보이고, 통년성 항원은 유럽 집먼지 진드기와 바퀴벌레, 화분류에서는 오리나무(alder)의 증가가 특징적이었다고 보고하였다. 이후 가장 근래의 데이터 는 2011년 6월 2014년 5월까지 부산의 한 대학병원에서 알레 르기 클리닉을 방문한 1400 명을 대상으로 흡입 알레르겐 항 원 총 24종 등에 관한 피부 단자 검사 결과로 $D f(35.5 \%), D p$ (33.3\%), cat(13.9\%), cockroach(11.1\%), $\operatorname{dog}(10.1 \%)$, birch (10.9\%), alder(10.8\%), beech(9.5\%), oak(9.4\%), mugwort (8.3\%)의 감작률을 보고한 바 있다. ${ }^{26)}$ 이 결과는 10 년 전의 결 과와 비교하여 각 항원별 감작률은 증가 했으나 원인 항원의 감작률의 순위는 큰 변화가 없다는 점이 주목할 만하다.

2008년 1월 2010년 12월까지 울산 지역에서 비염이나 기관 지 천식으로 진단된 환자 634명을 대상으로 흡입 항원으로 알레르기 피부 단자 시험을 시행한 결과 $D p(38.2 \%), D f(38.0 \%)$, birch(15.8\%), alder(15.3\%), hazel(14.2\%), oak(13.5\%), beech (10.8\%), mugwort(9.6\%), hop Japanese(5.2\%) 순서로 양성 률이 확인되었다. ${ }^{27)}$ 저자는 서문에서 울산은 급속한 산업화 와 도시화를 겪은 지역이므로 알레르기 질환 원인 항원의 변 동 양상이 다른 지역과 다를 것으로 예상하였는데, 실제 울산 호흡기 환자의 가장 주요한 항원은 다른 지역과 유사한 집먼 지 진드기였고, 꽃가루 항원의 경우 birch, alder, hazel, oak, beech 등에 대한 감작률이 $10 \%$ 이상으로, 이는 인근 부산에 서 시행된 결과와 비슷한 수치라고 고찰하였다. ${ }^{28)}$

강원 지역의 경우 고도가 높은 곳에 위치하고 있고, 산악 지역을 많이 포함하고 있으며 도시화, 산업화가 비교적 적게 진행된 지역이며 고령의 인구가 보다 많이 분포한다는 특징이 있다. 강원 지역의 경우, 2005년 6월 2007년 7월까지 15세 이 상, 50세 미만 726명 환자를 대상으로 한 피부 단자 검사 결 과 집먼지 진드기가 감작률이 가장 높아 $D p(33.8 \%), D f(31.0 \%)$, Tyrophagus putrescentiae(T. putrescentiae)(14.6\%), rabbit fur(13.3\%), trichophyton(13.0\%), cockroach(10.8\%), mugwort(10.9\%), orchard(7.3\%), $\operatorname{dog}(7.0 \%), \operatorname{birch}(6.7 \%)$ 순으로 보고하였다. 전체 대상 연령에서는 위의 순서로 나타났으나, 연 령별 분석을 시행하였을 때 20 29세 연령에서는 $D p(51.6 \%)$, Df(48.3\%), T. putrescentiae(19.7\%), rabbit fur(22.2\%), cockroach(16.4\%), mugwort(14.4\%), trichophyton(13.1\%), birch
(13.1\%), beech(11.8\%), dog(11.1\%), hazel(10.4\%), orchard (9.2\%)로 확인되며 꽃가루의 양성률이 전체보다 높아져 $10 \%$ 이하로 측정되던 것이 $10 \%$ 이상으로 측정되었다. ${ }^{29)}$ 강원도 다 른 지역과 마찬가지로 집먼지 진드기의 감작률이 가장 높았 고, 다른 지역과는 달리 토끼털에 대한 감작률이 높게 측정 되었는데 양성 반응을 보인 환자에서 토끼털에 대한 혈청 특 이 $\mathrm{IgE}$ 항체가 모두 확인된 것은 아니여서 다른 항원과의 교 차 항원성에 대한 가능성을 고려해야 할 것이라고 하였다.

10 년간 경기 남부 지역의 화분 항원 감작률의 변화에 대한 연구에서는 alder, oak, beech, bermuda grass, timothy grass, mugwort, ragweed, hop Japanese 화분과 Df, Dp, Aspergillus, Alternaria 등 총 13가지 항원에 대해 1999년과 2008 년 항원 각각의 감작률은 전반적으로 증가되는 양상을 보이 며, 특히 alder, oak, mugwort, ragweed, hop Japanese, timothy, $D p$, Alternaria는 유의한 감작률 증가를 나타내었다. 수목 화분인 오리나무, 떡갈나무, 너도밤나무와 잡초 화분인 쑥, 돼지풀, 환삼덩굴의 경우 모두 전 연령대에 감작률이 고르 게 증가되는 양상을 보였다. 환삼덩굴의 경우 10 세 미만의 소 아와 40 세 이상의 성인에서 증가가 더욱 뚜렷하게 나타났다 고 하였다. ${ }^{6}$

광주 전남 지역에서 시행된 흡입 항원에 대한 감작률과 기 온과의 관련성 분석에서 2002 2009년까지 1575명의 환자를 대상으로 하여 살펴본 연도별 감작률의 변화는 전체 환자를 대상으로 하였을 때 $D p, D f$, cat, dog, Alternaria, alder, beech, birch, hazel, oak, orchard grass, mugwort에 대한 감작률 은 유의한 변화가 없었다. 바퀴벌레, Trichophyton spp.에 대 한 감작률은 유의하게 감소하였다. ${ }^{30}$ 또한 2000년대 후반기 에 기온이 상승하는 추세를 보이고, 1 월과 3월의 평균 기온 상승이 두드려져 봄이 일찍 시작되며, 40 세 미만 환자들에서 수목 꽃가루(오리나무, 너도밤나무, 자작나무)와 목초 꽃가루 (rye grass, 독보리, 오리새)의 감작률이 2003 2008년까지 유 의하게 증가하였다. 반면 아토피 환자의 비율이나, 다른 통년 성 흡입 항원, 집먼지 진드기, 곰팡이, 바퀴벌레 항원에 대한 감작률은 유의한 증가가 없어서, 꽃가루 항원에 대한 감작률 증가는 꽃가루양 증가와 같은 외부의 요인에 의한 현상일 가 능성이 높다고 하였다.

\section{전국 기반의 연구 결과}

제4차 국민건강영양조사(Korea National Health and Nutrition Examination Survey) 대상자 중국 내 주요 대도시 에서 표본 추출된 110 명을 대상으로 감작된 알레르기 항원 의 종류를 확인한 결과가 2014년 발표되었는데, 11 종의 주요 흡입 알레르기 항원에 대한 피부 단자 검사 결과 $D f(40.9 \%)$, 
cockroach(23.6\%), mugwort(13.6\%), ragweed(10\%), oak (9.1\%), hop Japanese(9.1\%), dog dander(8.2\%)순으로 높게 감작되어 있는 것으로 확인되었다. ${ }^{3)}$

2017년도에 발표된 전국 5 개 지방의 청소년(초등학교 1년 고등학교 2년) 14678명[경기-인천; 7622명(52.2\%), 충청북도; 2212명(15.1\%), 광주; 1244명(8.3\%), 부산; 2213명(15.1\%), 제 주; 1407 명 $(9.6 \%)$, 평균 나이: $12.73 \pm 4.61]$ 을 대상으로 27 개 항원에 대한 지역에 따른 항원 양성률의 차이를 피부 단자 검 사로 조사한 연구에서는, ${ }^{31)}$ house dust mites $86.8 \%>$ pollen (tree 25.2\%>weed 19.9\%>grass 7.6\%)>mold $13.5 \%$ 의 순 으로 양성률이 보고 되었는데, $86.8 \%$ 양성률을 나타낸 house dust mites의 경우 5 개 지역별 양성률 차이가 크지 않았던 반 면, pollen(birch, alder, oak, Japanese cedar, mugwort, ragweed, hop Japanese)의 경우 통계적으로 유의한 $(p<0.001)$ 지역적 차이가 확인되어 제주 지역은 tree pollen의 양성률이 가장 높아 특히 Japanese cedar(38.1\%)가, 충청북도는 weed pollen이 우세하여 특히 hop Japanese(16.4\%), mugwort (11.7\%) 순서로 높게 나타났고, 부산의 경우엔 $\operatorname{birch}(23.9 \%)$, alder(21.0\%), oak(11.5\%)의 tree pollen의 순서로 높게 나타 났다. 이 연구는 pollen 항원의 지역별 감작률의 특징을 보여 주었다는 데에 의의가 있고, 흥미로운 점은 tree, weed, grass pollen 항원 중 각 지역별 우세하게 양성을 나타낸 항원 항 목들이 기존에 전국을 기반으로 한 연구 결과에서 양성으로 확인된 항원의 조성과 거의 비슷하다는 점과 5 개 지역별 항 원의 감작률의 절대적 수치의 높고 낮음에 차이는 있지만 전 체적 항원 순위에는 큰 변동이 없다는 점이다. ${ }^{31)}$

근래 서울, 강원, 인천, 경기, 충남, 광주, 대구, 부산, 경남, 제주 12 개 지역 18 세 이상 성인 28954명 환자의 피부 반응 검 사를 분석한 다기관 후향적 연구 결과에서 감작률이 높은 항 원은 Df, Dp, cat, birch, Tetranychus urticae, hazel, alder, mugwort, beech, oak로 확인되었고, 지역별로 제시된 양성률 이 높은 10 개의 항원은 충남 지역과 제주 지역을 제외하고 위의 전체 대상 10 위 항원들과 1 3개 정도 종류의 차이가 있 는 것으로 확인되었다. 충남 지역은 전체 항원과 차이가 있어 Tyrophagus putres, chrysan, hop Japanese, American cockroach의 항원이, 제주 지역은 orchard, Japanese cedar, rye, velvet, Tyrophagus putres의 항원이 10대 항원에 포함 되었다. ${ }^{32)}$ 연구에 포함된 지역 중 서울과, 경기, 제주 지역의 대 학병원은 2005년 1월 2013년 12월 등록된 환자를 대상으로 한 반면, 나머지 대부분의 경우 2010년대 초반 1 3년 정도의 기간에 등록된 환자 데이터를 분석 대상으로 하고 있어 해당 지역의 최신 항원 변화 추이를 비교해볼 수 있는 데이터임에 의의가 있는데, 다만 나이에 따른 분석이 시행되지 않아 아쉬
움이 있다.

\section{주요 감작 항원 패널 선정}

위에서 기술한 전국 및 국소 지역별 연구 결과를 종합하여 주요 알레르기 원인 항원을 6세 이하, 7 19세, 20 59세, 60세 이상 나이군별로 Table 3과 같이 패널을 선정하였다. 일반적 으로 연령이 증가할수록 항원에 대한 감작률이 감소하는 것 과, ${ }^{5)}$ 영유아기에서는 흡입 항원에 대한 알레르기보다 음식 알 레르기에 대한 유병율이 높고, 알레르기 비염은 학동기와 청 소년기에 가장 호발하는 나이인 것을 고려하여 나이군을 설 정하였다. ${ }^{33)}$ 이와 같은 조합은 제4차 국민건강영양조사의 항 원 양성률 결과에 상응하며, 부산, 제주 지역을 제외한 2017년 전국 청소년 대상 연구 결과의 pollen 항원의 결과와도 일맥 상통한다. 저자의 2014년 연구 결과에서, Tetranychus urticae 나 Tyrophagus putres 집먼지의 경우 단독 감작보다는 $D p$, $D f$ 와의 중복 감작이 대부분인 것으로 확인되어 이 두 진드기 의 경우 전국 10 대 항원에 포함되었음에도 전 연령군 패널에 서 제외하였다. Cockroach의 경우 여러 연구에서 10 20\%의 감작률을 나타내어 여전히 중요한 항원으로 인식되고는 있 으나, ${ }^{3,18,34)}$ 과거에 비해 감작률이 현저히 감소하였다는 결과 가 보고되고 ${ }^{35)}$ 20세 이후 감작률이 높은 것을 고려하여 7 19세의 패널 조합에서는 제외하였다. 제주의 경우엔 Japanese cedar 항원이 강하게 양성을 나타내고, rye, velvet 등이 10대 항원에 속하는 등 전국적인 데이터와 차이가 존재하는데, 이 렇게 지역적으로 강한 특색을 가진 항원의 경우 검사 시 개 별 추가를 하도록 권장하는 것이 좋을 것으로 생각된다.

항원에 대한 감작률의 변화가 생기려면 주로 대상 환자들

Table 3. New proposed allergens panel for allergic test

\begin{tabular}{rllll}
\hline \multicolumn{1}{c}{$\leq 6$ yrs } & 7-19 yrs & 20-59 yrs & \multicolumn{1}{c}{$\geq 0$ yrs } \\
\hline 1 & Df & Df & Df & Df \\
2 & Dp & Dp & Dp & Dp \\
3 & Beech & Dog & Dog & Cockroach \\
4 & Dog & Cat & Cat & Mugwort \\
5 & Oak & Birch & Birch & Oak \\
6 & Hop J & Beech & Cockroach & Beech \\
7 & Alternaria & Oak & Beech & Crysan \\
8 & & Alternaria & Oak & Ragweed \\
9 & & Hop J & Mugwort & Alder \\
10 & & Hazel & Hazel & A. fumigatus \\
11 & & Elder & Alder & \\
12 & & Alder & Hop J & \\
13 & & Mugwort & Crysan &
\end{tabular}

Dp: Dermatophagoides pteronyssinus, Df: Dermatophagoides farina, Hop J: hop Japanese, A. fumigatus: Aspergillus fumigatus 
의 유전자 변화가 발생하거나, 기후 변화, 대기오염 등의 복합 적인 환경 요인의 변화가 있어야 가능함을 고려할 때 적어도 10 년 이상의 기간 동안은 원인 항원의 구성 조합이 쉽게 바뀌 기는 어렵다는 결론이 가능하다. 그간의 연구 논문 결과를 참 고했을 때, 알레르기 비염 유병률의 증가에 따른 전체적 감작 률이 상승한다는 점, 초기 연구 결과가 나온 30여 년 전부터 현재까지 높은 감작률을 나타내는 항원의 종류가 크게 달라 지지 않았다는 점, 통년성 항원인 집먼지 진드기나 동물 상피 류 등의 경우엔 지역에 따른 큰 차이가 없고, 주로 화분류 항 원에서 지역적 차이가 있는데, 그것도 종류의 차이가 아닌 순 위의 차이임을 고려한다면, 주요 원인 항원을 조합하여 사용 하는 가능성 및 실효성에 더욱 무게가 실릴 수 있다.

\section{고 찰}

미세 먼지와 대기 오염의 증가로 인한 알레르기 질환이 증 가함에 따라 알레르기 질환과 비특이적인 면역 반응을 구분 하는 일은 임상에서 더욱 중요하게 되었다. 알레르기 비염은 환자의 증상 및 신체 검사 소견과 함께 실험실 검사를 통한 항원 특이 항체의 존재가 증명되고, 증상과의 상관관계가 인 정되어야 특정 원인 항원에 의한 알레르기 비염으로 진단이 가능하다.

최근 수행된 메타분석에서 피부 단자 검사의 민감도는 68 $100 \%$, 특이도는 70 91\%로 다양하게 보고되는 바, ${ }^{36)}$ 피부 단 자 검사는 알레르기 진단에 표준적인 검사이나, 소아 연령에 서는 협조가 필요한 점, 연령이 높아짐에 따라 피부 반응도가 감소하는 점, 약물 복용 여부와 피검자의 연령이 검사 시행 및 결과에 영향을 미친다는 점이 꾸준히 한계로 지적되어 왔 다. 이러한 한계점을 극복하는 방법으로 간단한 채혈로 수십 종의 항원을 동시에 측정할 수 있는 선별 검사로 실제 임상에 서 사용되는 ImmunoCAP ${ }^{\circledR}$ 은 전세계적으로 널리 사용되는 정량적(quantitative)인 검사라서 면역치료와 같은 치료를 시 행한 전·후의 항원 특이 항체량의 변화를 측정할 수 있는 방 법이므로 면역 치료가 알레르기 비염치료에 주(mainstry)가 되고 있는 요즘 예전보다 더욱 사용의 정당성을 갖는다고 하 겠다. 면역치료를 고려하지 않는다면 혼합 항원으로 검사를 하는 것이 더 효율적이며, 면역치료를 염두한다면 통년성, 계 절성 항원 중에서 감작률이 높은 항원을 선택적으로 검사하 는 것이 적절한 치료 계획을 세우는 데 현명한 방법일 것이다.

본 연구의 목적은 알레르기 원인 항원의 패널을 조합하여 실제 임상진료 시에 검사 항원을 선택하는 데 가이드를 제공 하고자 하는 것이다. 근거 중심 의학의 목표를 실현하고자 전 국 단위의 명확한 연구 결과들을 바탕으로 적절한 항원 검사
조합을 설정하여 이를 임상진료에 적용한다면 진료의 질을 향상시킬 수 있을 뿐만 아니라 의료 비용 감소가 가능할 것이 다. 이러한 조합의 사용을 권장하고 지속하려면 전국의 성인 및 소아에서 주요 원인 항원 감작률의 종적인 변화가 확인 가 능해야 하며, 그러기 위해서는 본 연구에서 제시된 패널 사용 방법의 기존 방법 대비 효율성 및 정확성 검증이 시행되어야 한다. 전국 단위의 항원 감작에 관한 데이터베이스 플랫폼이 구축된다면 통합적이고, 체계적인 연구가 수행될 수 있을 것 이다.

\section{ORCID}

Chae-Seo Rhee https://orcid.org/0000-0002-1361-8585

\section{REFERENCES}

1) Suh M, Kim HH, Sohn HM, Kim KE, Kim C, Shin DC. Prevalence of allergic diseases among Korean school-age children: A nationwide cross-sectional questionnaire study. J Korean Med Sci 2011;26(3): 332-8.

2) Park HS, Choi GS, Cho JS, Kim YY. Epidemiology and current status of allergic rhinitis, asthma, and associated allergic diseases in Korea: ARIA Asia-Pacific workshop report. Asian Pac J Allergy Immunol 2009;27(2-3):167-71.

3) Park HJ, Lee JH, Park KH, Ann HW, Jin MN, Choi SY, et al. A nationwide survey of inhalant allergens sensitization and levels of indoor major allergens in Korea. Allergy Asthma Immunol Res 2014;6(3):222-7.

4) Kim KE, Kim KS, Kim YK, Na YH, Min KU, Park HS, et al. National guideline for the diagnosis and management of allergic rhinitis. J Asthma Allergy Clin Immunol 1999;Supple 19(90);809-85.

5) Skassa-Brociek W, Manderscheid JC, Michel FB, Bousquet J. Skin test reactivity to histamine from infancy to old age. J Allergy Clin Immunol 1987;80(5):711-6.

6) Lee JW, Choi GS, Kim JE, Jin HJ, Kim JH, Ye YM, et al. Changes in sensitization rates to pollen allergens in allergic patients in the southern part of Gyeonggi province over the last 10 years. Korean J Asthma Allergy Clin Immunol 2011;31(1):33-40.

7) Keum DG, Kim BI. A study on the production of allergen panels. J Asthma Allergy Clin Immunol 1999;19(6):920-26.

8) Kim TB, Kim KM, Kim SH, Kang HR, Chang YS, Kim CW, et al. Sensitization rates for inhalant allergens in Korea; A multi-center study. J Asthma Allergy Clin Immunol 2003;23(3):483-93.

9) Shamji MH, Kappen JH, Akdis M, Jensen-Jarolim E, Knol EF, Kleine-Tebbe J, et al. Biomarkers for monitoring clinical efficacy of allergen immunotherapy for allergic rhinoconjunctivitis and allergic asthma: An EAACI position paper. Allergy 2017;72(8): 1156-73.

10) Loureiro G, Tavares B, Chieira C, Pereira C. Effect of Dermatophagoides specific immunotherapy on cutaneous reactivity. Eur Ann Allergy Clin Immunol 2007:39(1):5-8.

11) Letrán A, Espinazo M, Moreno F. Measurement of $\operatorname{IgE}$ to pollen allergen components is helpful in selecting patients for immunotherapy. Ann Allergy Asthma Immunol 2013;111(4):295-7.

12) Jarolim E, Poulsen LK, Stadler BM, Mosbech H, Oesterballe O, Kraft D, et al. A long-term follow-up study of hyposensitization with immunoblotting. J Allergy Clin Immunol 1990;85(6):9961004.

13) Di Lorenzo G, Mansueto P, Pacor ML, Rizzo M, Castello F, Martinelli N, et al. Evaluation of serum s-IgE/total IgE ratio in 
predicting clinical response to allergen-specific immunotherapy. J Allergy Clin Immunol 2009;123(5):1103-10, 1110.e1-4.

14) Ciprandi G, De Amici M, Giunta V, Marseglia GL. Comparison of serum specific IgE and skin prick test in polysensitized patients. Int J Immunopathol Pharmacol 2010;23(4):1293-5.

15) Alesina R, De Amici M, Ciprandi G. Serum IgE discriminates allergy from sensitisation better than skin testing. Allergol Immunopathol (Madr) 2014;42(2):171-3.

16) Kang SY, Choi BW, Moon HB, Min KU, Kim YY. The prevalence of immediate skin reactions in patients with respiratory allergies. $\mathrm{J}$ Asthma Allergy Clin Immunol 1984;4(1):49-56.

17) Ko YH, Park SY, Lee JH, Koo GJ, Koo SK, Lee SH, et al. A clinical statistics on the offending allergens of allergic rhinitis. Korean J Otorhinolaryngol-Head Neck Surg 1998;41(1):42-7.

18) Lee JE, Ahn JC, Han DH, Kim DY, Kim JW, Cho SH, et al. Variability of offending allergens of allergic rhinitis according to age optimization of skin prick test allergens. Allergy Asthma Immunol Res 2014; 6(1):47-54.

19) Eigenmann PA, Atanaskovic-Markovic M, O'B Hourihane J, Lack G, Lau S, Matricardi PM, et al. Testing children for allergies: Why, how, who and when: An updated statement of the European Academy of Allergy and Clinical Immunology (EAACI) Section on Pediatrics and the EAACI-Clemens von Pirquet Foundation. Pediatr Allergy Immunol 2013;24(2):195-209.

20) Burbach GJ, Heinzerling LM, Edenharter G, Bachert C, BindslevJensen C, Bonini S, et al. GA ${ }^{2}$ LEN skin test study II: Clinical relevance of inhalant allergen sensitizations in Europe. Allergy 2009;64(10): 1507-15.

21) Heinzerling L, Mari A, Bergmann KC, Bresciani M, Burbach G, Darsow U, et al. The skin prick test - European standards. Clin Transl Allergy 2013;3(1):3.

22) Global Initiative for Asthma. Global strategy for asthma management and prevention 2018. [cited 2018 Sep 17]. Available from: URL: www. ginasthma.org.

23) Schulman ES, Pohlig C. Rationale for specific allergen testing of patients with asthma in the clinical pulmonary office setting. Chest 2015;147(1):251-8.

24) Bang JH, Kim YJ, Shin HS, Lee BJ. Clinical analysis of allergic rhinitis in Seoul. J Rhinol 1996:3(2);130-4.

25) Lee SK, Kim SW, Yeo SG, Cho JS. Analysis of allergic rhinitis according to new classification regarded by ARIA(Allergic Rhinitis and its Impact on Asthma) Guideline: Difference with classification by antigen detected by Multiple Allergen Simultaneous Test (MAST). Korean J Otolaryngol-Head Neck Surg 2006;49(10):991-6.

26) Nam YH, Jeon DS, Lee SK. Comparison of skin prick test and serum specific IgE measured by ImmunoCAP system for various inhalant allergens. Allergy Asthma Respir Dis 2015;3(1):47-53.

27) Choi SW, Lee JH, Kim YH, Oh IB, Choi KR. Association between the sensitization rate for inhalant allergens in patients with respiratory allergies and the pollen concentration in Ulsan, Korea. Korean J Med 2014;86(4):453-61.

28) Kim KH, Kim KT, Lee SK, Park HS, Lee YM, Nahm DH, et al. Sensitization rates for inhalant allergens in patients with respiratory allergy in Busan. J Asthma Allergy Clin Immunol 2005;25:59-63.

29) Lee MK, Lee WY, Yong SJ, Shin KC, Lee SN, Lee SJ et al. Sensitization rates to inhalant allergens in patients visiting a university in Gangwon region. Korean J Asthma Allergy Clin Immunol 2011;31(1):27-32.

30) Yoon BJ, Kim SH, Kim DH, Koh YI. Longitudinal changes of sensitization rates to inhalant allergens in patients with allergic diseases from Gwangju and Chonnam areas: Their association with annual changes in temperature. Korean J Asthma Allergy Clin Immunol 2011;31(2):93-104.

31) Sung M, Kim SW, Kim JH, Lim DH. Regional difference of causative pollen in children with allergic rhinitis. J Korean Med Sci 2017; 32(6):926-32.

32) Kang MG, Kim MY, Song WJ, Kim S, Jo EJ, Lee SE, et al. Patterns of inhalant allergen sensitization and geographical variation in Korean adults: A multicenter retrospective study. Allergy Asthma Immunol Res 2017;9(6):499-508.

33) Barbee RA, Kaltenborn W, Lebowitz MD, Burrows B. Longitudinal changes in allergen skin test reactivity in a community population sample. J Allergic Clin Immunol 1987;79(1):16-24.

34) Eun YK, Kim SW, Lee IY, Cho JS. Cockroach allergic rhinitis in the urban area in Korea: Sensitivity and diagnosis. Korean J Otorhinolaryngol-Head Neck Surg 2004;47(8):747-50.

35) Park HJ, Lim HS, Park KH, Lee JH, Park JW, Hong CS. Changes in allergen sensitization over the last 30 years in Korea respiratory allergic patients: A single-center. Allergy Asthma Immunol Res 2014;6(5):434-43.

36) Nevis IF, Binkley K, Kabali C. Diagnostic accuracy of skin-prick testing for allergic rhinitis: A systematic review and meta-analysis. Allergy Asthma Clin Immunol 2016;12:20.

\section{정답 및 해설}

1. 답 (3)

해 설 전두사골동 점액낭종(frontoethmoid mucocele). 최근에는 대부분 비내시경 접근법에 의한 조대술(marsupialization)을 시행하고 있다.

참고 문헌: 대한이비인후과학회. 이비인후과학-비과. 파주: 군자출판사;2018. p.548. 